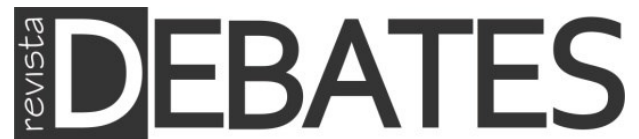

\title{
O poder político da ANAMATRA e a Lei Constitucional
}

\author{
The political power of ANAMATRA and the Constitutional Law
}

\section{Lígia Barros de Freitas}

\section{Resumo}

O presente artigo analisa a atuação política da Associação Nacional dos Magistrados da Justiça do Trabalho (ANAMATRA) no processo constituinte de 1987-88 e na Reforma do Poder Judiciário em 2004. O objetivo é mostrar que os ganhos que a ANAMATRA obteve no processo da Emenda Constitucional da Reforma do Poder Judiciário advieram da sua atuação anterior na Asssembleia Nacional Constituinte de 1987-1988 e de sua atuação conjunta com o Tribunal Superior do Trabalho (TST). O referencial teórico utilizado é o institucionalismo.

\section{Palavras-chave}

ANAMATRA; Assembleia Nacional Constituinte de 1987-1988; Reforma do Poder Judiciário; Institucionalismo.

\begin{abstract}
This article analyzes the political activity of the National Association of Labor Court Judges (ANAMATRA) in the constitutional process of 1987-88 and in the Judicial Reform of 2004. The goal is to show that the gains achieved by ANAMATRA in the Judicial Reform stemmed from its previous actions in the National Constituent Assembly of 1987-1988, and the joint action with the Superior Labor Court (TST). The work was done with the theoretical framework of the institutionalism.
\end{abstract}

\section{Keywords}

ANAMATRA; National Constituent Assembly of 1987-1988; Judicial Reform; Institutionalism. 


\section{Introdução $^{1}$}

Segundo Taylor (2007), as pesquisas devem dar maior atenção ao papel político do Judiciário e a sua incorporação nas análises do sistema político brasileiro, frente ao fato de que os integrantes do Poder Judiciário brasileiro têm capacidade de influenciar a atuação dos Poderes Executivo e Judiciário. Carvalho (2004), no mesmo sentido, já argumentou a necessidade de ampliar os horizontes de análises, com problematização da judicialização para responder às seguintes perguntas: a) até que ponto os juízes modificam as leis ou atos dos demais poderes? b) até que ponto essas decisões influenciam na aplicação de políticas públicas?

Atento a esses questionamentos, o objetivo do presente artigo é contribuir para os estudos sobre a atuação política do Poder Judiciário Trabalhista. A pesquisa focaliza a atuação política da Associação Nacional dos Magistrados do Trabalho (ANAMATRA) junto ao Poder Legislativo do Brasil, em dois momentos específicos: 1) durante a Assembleia Nacional Constituinte (ANC) de 1987-1988 e 2) no período da reforma do Poder Judiciário, ou seja, no trâmite das Propostas de Emendas Constitucionais (PECs) que originaram as Emendas Constitucionais 24/1999 e 45/2004. Em ambos os períodos, o estudo analisa os dispositivos sobre os direitos trabalhistas e sobre os que trataram da estrutura e competência da Justiça do Trabalho. Com isso, busca entender qual a importância da ANAMATRA como ator responsável pelas mudanças do Direito do trabalho no período de 1987 a 2004.

$\mathrm{Na}$ literatura brasileira há algumas mençóes ao papel da ANAMATRA. Morel e Pessanha (2006), em pesquisa na qual identificaram a origem social dos magistrados do trabalho e suas características de gênero e idade, apontaram que a ANAMATRA serviu como um mecanismo de socialização. As mençóes mostram a forte e decisiva participação da ANAMATRA e das Associações dos Magistrados do Trabalho (Amatra) - associações de âmbito regional - junto ao Legislativo, durante todo o processo da Reforma do Poder Judiciário. Engelmann (2006), em estudo sobre o maior engajamento político dos juízes do trabalho, apontou que a ANAMATRA, influenciada pela experiência da Amatra da 4o Região (Paraná, Santa Catarina e Rio Grande do Sul), passou a concluir seus Congressos anuais com teses coletivas do trabalho que "são compostas de princípios doutrinários, que traduzem tomadas de posição políticas e jurídicas dos magistrados, refletindo no momento das decisões

\footnotetext{
${ }^{1} \mathrm{O}$ presente artigo trata-se de uma versão modificada de alguns capítulos da tese de Doutorado intitulada "A consolidação institucional do Tribunal Superior do Trabalho (TST) na longa Constituinte (1987-2004)", financiada pela Fundação de Amparo à Pesquisa do Estado de São Paulo (FAPESP).
} 
judiciais" (ENGELMANN, 2006, p. 187). Artur (2012), em sua pesquisa sobre os atores coletivos que atuam junto ao TST, conclui que a ANAMATRA tem obtido relativo sucesso em avançar nas pautas pela democratização do Poder Judiciário Trabalhista e pelo acesso da sociedade à Justiça do Trabalho.

Para a análise proposta, utilizaremos o referencial teórico do institucionalismo histórico, que entende que os indivíduos calculam com base em seus interesses, no entanto, por possuírem diferentes visões de mundo, dado sua posição e seu contexto social, os interesses são construídos politicamente (IMMERGUT, 1996). Assim, existem atores coletivos formados por cálculos e cultura, onde as instituiçôes oferecem a certos grupos ou interesses um acesso desproporcional ao processo de decisão, ou seja, há relações assimétricas de poder (HALL e TAYLOR, 2003; THÉRET, 2003; THELEN e STEINMO, 1992).

Os seguidores dessa vertente, segundo Hall e Taylor (2003), valorizam o desenvolvimento histórico, tornando-se defensores de uma causalidade social dependente da trajetória percorrida pela instituição - path dependent. Rejeitam o entendimento tradicional, até então prevalecente nas teorias comportamentalistas e pluralistas, de que as mesmas forças ativas produzem os mesmos resultados em todos os lugares. O institucionalismo histórico busca explicar como as próprias instituições, através de políticas adotadas no passado, acabam condicionando as políticas ulteriores. Seus teóricos, situando as instituiçóes numa cadeia causal, deixam espaços para outros fatores, em particular, o desenvolvimento socioeconômico e a difusão de ideias, embora destaquem o papel das instituiçôes na vida política.

Thelen e Steinmo (1992) apontaram duas importantes agendas de pesquisa que têm emergido, nos últimos anos, dentro da escola do institucionalismo histórico, com a finalidade de confrontar a forte tendência estática das análises institucionais que negligencia o seu dinamismo. A primeira atenta para o melhor entendimento dos mecanismos das mudanças institucionais, atribuindo grande importância às regras, formais ou informais, que acabam por distribuir poderes desiguais entre os atores. $\mathrm{Ou}$ seja, as organizaçôes políticas influenciam no grau de poder que os atores podem ter sobre os resultados políticos (MAHONEY e THELEN, 2010) ${ }^{2}$. A segunda agenda é um esforço para compreender o papel das ideias na política, na história e nas

\footnotetext{
${ }^{2}$ Segundo Mahoney e Thelen (2010), no mundo real os agentes de mudança não trabalham sozinhos, eles agem com outros agentes institucionais. $\mathrm{O}$ sucesso dos vários tipos de agentes em gerar mudança depende das coalizóes deliberadas ou surgidas nas lutas distributivas, levando-se em conta o contexto político e as oportunidades dentro da instituição. Além disso, é necessário considerar também que os atores estão inseridos, simultaneamente, em diferentes instituiçóes.
} 
instituições, buscando explicaçôes sobre por que certas ideias, e não outras, dominam o discurso político. Perseguem um melhor entendimento sobre os caminhos das ideias, valores e crenças que afetam a história, política e instituições (LEVI, 1991) ${ }^{3}$.

A agenda da pauta política é analisada através das votaçóes de leis e artigos na área do trabalho. Do período da ANC de 87/88 são analisadas as atas da Subcomissão dos Direitos dos Trabalhadores e Servidores Públicos, Comissão da Ordem Social (ambas responsáveis pelas matérias de direito do trabalho), Subcomissão do Poder Judiciário e do Ministério Público, da Comissão da Organização e Sistema de Governo (ambas responsáveis pela matéria sobre estrutura e competência da Justiça do Trabalho), Comissão de Sistematização e dos dois turnos em Plenário. Sobre a Reforma do Poder Judiciário foram analisadas as atas sobre a tramitação da PEC 92/1996 na Câmara dos Deputados e da PEC 29/2000 no Senado, ambas referentes à Emenda Constitucional 45/2004. Em relação à Emenda Constitucional 24/1999, que extinguiu os juízes classistas e foi apreciada no bojo da reforma do Poder Judiciário, foram analisadas as atas da PEC 63/1995 que tramitou no Senado Federal, e da PEC 33/1999 que tramitou na Câmara dos Deputados. Igualmente, o artigo baseia-se em entrevista com Antonio Carlos Facioli Chedid, que na época da Constituinte era Juiz Presidente da ANAMATRA.

\section{A ANAMATRA na Constituinte de 1987/88: a extinção da representação classista}

A ANAMATRA, associação de caráter nacional dos Magistrados do Trabalho ${ }^{4}$, centrou sua atuação política na ANC de 1987/88 sobre a estrutura e competência da Justiça do Trabalho, não demonstrando interesse nos artigos sobre direito do Trabalho.

\footnotetext{
${ }^{3}$ Em seu estudo, Levi (1991) caracteriza as instituições formais como regras socialmente construídas que refletem uma distribuição de recursos de poder. Levi sugere que ocorre a mudança institucional na medida em que muda essa distribuição de poder e há o abandono de submissão por pessoas e grupos aos arranjos institucionais. Esclarece a autora que a mudança é mais provável quando aumenta a eficiência dos indivíduos que a desejam, o que diminui o poder de veto daqueles que são servidos pelos arranjos institucionais existentes. Acredita que, quando há o abandono do "consenso contingente" (obediência quase voluntária) à instituição existente, se precipita a mudança com o aumento do poder de barganha daqueles que não aceitam ou deslegitimam os recursos coercitivos vigentes.

${ }^{4}$ No Brasil, há as Amatras, que são as associações regionais dos juízes do trabalho, e a ANAMATRA, de caráter nacional, da qual as Amatras fazem parte.
} 
$\mathrm{Na}$ escolha dos participantes das audiências públicas na Subcomissão do Poder Judiciário e do Ministério Público na ANC de 1987/885, conforme a análise detalhada dos Anais da Constituinte, logo de início, houve manifestações dos constituintes sobre a necessidade de receber representantes da Justiça do Trabalho, em específico, dos magistrados trabalhistas. Dentre outras associações, a ANAMATRA foi convidada para audiência pública ${ }^{6}$ Segundo o presidente da ANAMATRA, em entrevista dada a esta pesquisa, a participação da associação foi conquistada pela Amatra de São Paulo junto a alguns constituintes, sendo um deles o relator Plínio de Arruda Sampaio (PT-SP).

A ANAMATRA participou de audiências públicas ${ }^{7}$ e se utilizou de outros recursos formais de participação na ANC de 1987/1988. Engelmann (2006) apontou o papel desempenhado pelas associaçóes de magistrados e promotores na conjuntura da Constituinte, com manifestações públicas em defesa de suas prerrogativas institucionais, definindo o seu "papel político".

Em audiência pública, o presidente da ANAMATRA, o juiz Antônio Carlos Facioli Chedid", relatou que trataria do "que a magistratura do Trabalho pretende e pensa". Elucidou que fazia dois anos que a magistratura trabalhista se preparava, o que culminou com a elaboração de um texto de proposta de redação do texto constitucional. $\mathrm{O}$ documento entregue à subcomissão, de maneira geral, propunha $\mathrm{o}$ aumento da competência da Justiça do Trabalho ${ }^{10}$, o aumento do número de

5 A ANC de 1987/88 foi instituída por 24 subcomissões que apresentariam suas propostas para oito Comissões Temáticas que, por sua vez, formulariam os anteprojetos à Comissão de Sistematização, que levaria a discussão para o plenário geral da ANC. Com esta engenharia da ANC, todos os constituintes participariam, diretamente, ao menos de uma fase.

6 Também foram convidadas a Associação Nacional dos Juízes Classistas da Justiça do Trabalho (Anajucla) e a Associação Brasileira dos Advogados Trabalhistas (Abrat).

${ }^{7}$ No presente texto, quando houver referência à audiência pública, as informaçóes da sua ocorrência foram retiradas dos Anais da Assembleia Nacional Constituinte ou da tramitação de alguma Emenda Constitucional, conforme o tema abordado.

${ }^{8}$ Antônio Carlos Facioli Chedid, na época em que foi presidente da ANAMATRA, era juiz de primeiro grau na Junta de Conciliação e Julgamento de Lages - Santa Catarina. Foi promovido ao cargo de juiz do Tribunal Regional do Trabalho (TRT) da 12a Região em abril de 1996, sendo eleito presidente para o biênio 1998/2000. Foi vice-coordenador do Colégio de Presidentes e Corregedores dos TRTs (1998/1999).

9 Conforme se verifica em Brasil (1987, p. 33).

${ }^{10}$ A Justiça do Trabalho, em regra, até a Emenda Constitucional 45/2004, era competente para julgar conflitos oriundos de relação de emprego, ou seja, relaçóes regidas pela Consolidação das Leis Trabalhistas (CLT) nas quais havia a caracterização de uma das partes como empregado. Segundo o mencionado diploma legal, é empregado toda pessoa física que prestar serviços de natureza não 
Ministros no TST e extinção dos juízes classistas da Justiça do Trabalho ${ }^{11}$. Confirmando a tese de pouco interesse da Justiça do Trabalho nas questóes referentes à legislação do trabalho na ANC, o documento apresentado pela ANAMATRA somente tratou sobre a estrutura e competência da Justiça do Trabalho ${ }^{12}$.

Antônio Carlos Facioli Chedid, em entrevista, relatou que a atuação da ANAMATRA, nesta época, devia-se mais ao associativismo dos juízes trabalhistas de primeiro grau, com poucas participações de juízes de TRTs, embora não houvesse um tensionamento entre os dirigentes da Associação e os TRTs.

A crítica aos juízes classistas consistia em um dos pontos mais importantes do projeto defendido pela ANAMATRA. O argumento utilizado era de que o vocalato tratava-se de resquício fascista, instrumento político da era Vargas, criador de empreguismo e mantenedor de instrumento de ingerência ou de interesses na Corte Trabalhista. Além disso, o sistema tripartite custava caro para os cofres da União, principalmente com as aposentadorias dos juízes classistas após cinco anos de exercício na função. Outra censura da ANAMATRA era que os juízes classistas prejudicavam a unificação e assentamento da jurisprudência do TST, dada a sua alternância e por produzirem uma jurisprudência "acientífica"13.

Ainda, em audiência pública, relatou o que considerava uma farsa: a inoperância dos classistas que não se manifestavam e julgavam concordando com o voto do presidente da JCJ (juiz togado). Para ele, a representação classista havia prestado relevantes serviços à nação, entretanto, naquele momento histórico, não

eventual a empregador, sob a dependência deste e mediante salário. O que estava em discussão nessa época era se a Justiça do Trabalho deveria ser também competente para julgar outras relaçóes de trabalho, como estatutários, eventuais, autônomos, dentre outros.

11 Da sua criação até a Emenda Constitucional 24/1999, a Justiça do Trabalho foi uma estrutura tripartite. Desde primeiro grau, na época denominada de Junta de Conciliação e Julgamento, passando pelos TRTs e chegando ao TST, compunham seus órgãos os juízes classistas - um representando o capital e o outo o trabalho, ambos sendo indicados pelos sindicatos correspondentes, para exercício da funçấo por tempo determinado - e o representante do Estado, o juiz togado, concursado.

${ }^{12}$ Cópia do documento nos foi gentilmente fornecida por Antônio Carlos Facioli Chedid quando realizamos, em seu escritório de advocacia, entrevista em 25 de agosto de 2011, na cidade de Florianópolis - Santa Catarina.

${ }^{13}$ Conforme sua fala transcrita nas Atas da ANC: "Não é mais concebível, a nosso ver, no atual estágio social, uma Justiça voltada exclusivamente para um segmento da sociedade, ainda que dela participem membros leigos com poder decisório, sem qualquer burilamento teórico, abstrato, e - o que é bem nefasto - com interesse mediato e imediato na solução dos litígios, já que tais membros, representantes classistas, buscam a porta do Judiciário para obtenção de vantagens pessoais, promoção e prestigio perante os órgãos de origem, ou seja, seus sindicatos" (BRASIL, 1987, p. 33). 
mais era possível conceber essa representação, pois se tratava de participação de pessoas leigas com mandatos temporários e com outros interesses no âmbito da Justiça.

Em sua fala em audiência pública, apontou que o STF já havia se posicionado, com publicação no Diário Oficial, pela extinção da representação classista nos tribunais. Mencionou que a CUT e muitas federaçôes já haviam se posicionado contrárias à representação classista, argumentando que não seria possível conjugar independência e pluralidade sindical com a sua participação na Justiça do Trabalho.

Com relação aos juízes togados, ainda em audiência, a ANAMATRA propôs o aprimoramento e o incentivo à carreira do magistrado, com nomeações dos juízes dos Tribunais, feitas pelo presidente do mesmo Tribunal, afastando assim os critérios políticos.

A competência nos dissídios individuais foi outro ponto retomado pelo presidente da ANAMATRA em audiência pública. Chedid propôs a sua ampliação para toda e qualquer relaçáo de trabalho, incluindo os trabalhadores eventuais, os empreiteiros e os servidores públicos federais, bem como para açóes que decorriam de uma relação de emprego como acidente de trabalho. Segundo entendia, a ampliaçáo de competência vinha ao encontro da jurisprudência que, ousadamente e afrontando o texto constitucional, vinha julgando algumas ações não abrigadas na legislação. No documento entregue pela ANAMATRA, a competência da Justiça do Trabalho era ampliada para mandado de segurança, habeas corpus e açóes conexas em matéria de sua competência.

O presidente da ANAMATRA posicionou-se no sentido de que a representação classista já não representava os litigantes de forma satisfatória frente às mais de três mil ocupaçóes disciplinadas pelo Código de Ocupaçóes Profissionais, de tal modo que, um representante metalúrgico pouco poderia auxiliar o juiz togado quando a reclamação versasse sobre um bancário.

Se, por um lado, a ANAMATRA sugeriu o aumento de competência para os dissídios individuais, por outro, frente ao volumoso número de processos que já assombrava o Judiciário, defendeu em audiência pública a criação de órgãos extrajudiciais, com a participação dos sindicatos e de empregadores onde os litígios poderiam ser resolvidos através de acordos. Seria uma fase pré-processual conciliatória, criada junto aos próprios sindicatos, homologando as rescisóes contratuais. 
Quanto ao poder normativo ${ }^{14}$, a ANAMATRA, através de Chedid, em audiência pública, defendeu a sua ampliaçáo, argumentando que o mesmo praticamente não existia, visto que os Tribunais apenas estavam concedendo aquilo que estava na lei, pois os que eram mais ousados e acrescentavam novas condiçóes de trabalho nos dissídios coletivos acabavam por ver suas decisôes reformadas pelo STF, ou então suspensas pelo Presidente do TST. Apontando que o TST inibia a utilização do poder normativo pelos TRTs, notamos que a ANAMATRA mediava os interesses dos juízes de primeira instância, principalmente, e dos juízes dos TRTs, assumindo uma postura de enfrentamento com a cúpula do Judiciário Trabalhista, o TST.

Antônio Carlos Facioli Chedid, em entrevista antes mencionada, confirmou a clivagem entre ANAMATRA e TST na época da Constituinte. O seu relato sobre o posicionamento do TST favorável aos classistas, embora não fosse público, apontou para o distanciamento do TST em relação às outras instâncias do Judiciário Trabalhista, o que aponta que o TST neste período mantinha sua imagem de poder passivo frente aos demais poderes, embora seu presidente, Marcelo Pimentel, tivesse atuado nos bastidores da ANC, e sobre a clivagem entre a Cúpula e as demais instâncias da Justiça do Trabalho ${ }^{15}$.

Em continuação à entrevista, relatou também sobre a nomeação política dos Ministros do TST, que impossibilitava o acesso democrático e por mérito da grande maioria dos juízes trabalhistas, e sobre a não aceitação pelo TST, que se encontrava muito fechado para as instâncias inferiores e para o movimento associativista dos magistrados ${ }^{16}$.

\footnotetext{
${ }^{14}$ Poder Normativo: "Competência dos Tribunais do Trabalho para estabelecer normas e condiçôes, por sentença, em dissídios coletivos, visando à sua solução. $\mathrm{O}$ poder normativo não pode extrapolar o limite da lei, mas pode ampliar vantagens legalmente asseguradas, desde que não interfira no poder de comando do empregador. Está previsto no art. 114, $\$ 2^{\circ}$, da Constituição Federal. Nos países em que os tribunais trabalhistas solucionam conflitos de natureza socioeconômica essa competência tem o nome de poder arbitral" (PODER NORMATIVO, 2012).

15 Segundo Chedid, Marcelo Pimentel tinha pretensões de exercer cargos políticos após sua aposentadoria, por isso náo tinha interesse em tomar um posicionamento público, em nome do TST, contra a representaçáo classista, para não se indispor com os empregados e com os empregadores que defendiam o vocalato.

16 "O TST estava enclausurado, era superior em todos os sentidos da palavra: comunicação do Ministro com juiz, não tinha, o juiz tinha que chamá-lo de Excelência. Era um patamar muito grande para a gente chegar, então isso, por si só, os separava. O movimento associativo era uma coisa repudiável pela magistratura mais antiga, que não aceitava o juiz reivindicar, o juiz postular, o juiz sugerir. O juiz era aquele concebido por Maquiavel, fica sentando olhando para o que os caras dizem, o que a lei diz, depois diz como é que é e vai embora. [...] Não se envolve. Então essa era a visão,
} 
A ANAMATRA, em audiência, não se posicionou com relação à competência para julgar greves, mesmo após provocação do constituinte Maurício Corrêa (PDTDF) criticando a Justiça do Trabalho por julgar sempre pela sua ilegalidade. Em resposta à provocação, o representante da ANAMATRA somente constatou que as decisões trabalhistas em matéria de greve eram o caos da nação, já que o trabalhador não as cumpria, havia disparidade de entendimento nos próprios Tribunais: julgavam-se incompetentes para julgar sobre a greve, entendendo que somente juízes de primeiro grau poderiam fazê-lo, outros se davam por competentes, e a lei considerava todas as greves ilegais.

A ANAMATRA também se articulou nos "bastidores". Conforme entrevista realizada com o presidente da ANAMATRA, aconteciam muitos jogos políticos que se davam fora da arena das subcomissões e comissóes, com conversas em gabinetes e encontros ${ }^{17}$.

A luta com relação à representação classista foi intensa e para além dos debates registrados em ata. Em entrevista, o presidente da ANAMATRA, além de relatar a sua proibição de entrar no TST, nos relatou que na época foi cogitado ser processado pela ANC pelo envio de correspondência aos presidentes das Amatras, alertando-os sobre a conduta dos constituintes que haviam se comprometido a votarem pela extinção dos classistas e assim não o fizeram. O assunto chegou ao presidente da

ficavam distantes, não gostava da ANAMATRA, não aceitava a ANAMATRA, como uma associação, como uma reuniấo de juízes, tanto é que às vezes que eu saí, muitas vezes sai de lá, de Brasília, o Corregedor-Geral ligava para o Corregedor-local para saber se eu estava realmente autorizado para me afastar da jurisdição. Só para você ter uma ideia, a minha associação, a Amatra de Santa Catarina, durante todo o tempo que eu fui presidente da ANAMATRA, não divulgou nenhum ato que eu fiz, nenhum, todas as associações, no Brasil inteiro, divulgaram, aqui não, porque o presidente da época queria ser Ministro, e precisava do apoio da representantes classistas, e se ele divulgasse um ato contra a representação classista, ele não seria Ministro” (sic) (CHEDID, 2011).

17 "Um único cara votou contra [permanência dos classistas], Nelson Jobim, ele levantou e deu um discurso, ele falou a nossa tese, o único, ninguém mais teve coragem de se opor à representação. Chegamos a conversar com ele [...] Era o Plínio que tinha todo o poder ali. Eu me lembro os que tinham maior participação, Plínio, Jairo Carneiro, Bernardo Cabral. A ANAMATRA conversava com Bernardo Cabral, era um cara bem receptivo, inteligente, culto. O pessoal de São Paulo tinha contato permanente com ele. Ele nos recebeu várias vezes, mandou chamar lá no Gabinete, algumas oportunidades, não sei se era só para fazer uma média política ali, colocavam os deputados, pediam para a gente explanar, explicar o que era, contar a história da Justiça do Trabalho para os que não conheciam, ou para os que tinham uma visão um pouco distorcida” (sic) (CHEDID, 2011). 
ANC para ser resolvido, mobilizando outros juízes, que o defenderam e enviaram telegramas e correspondências ao presidente da ANC, Ulysses Guimarães ${ }^{18}$.

As Atas da Assembleia Nacional Constituinte e a entrevista apresentada, analisadas sob o enfoque do institucionalismo histórico, embasam a conclusão de que havia duas clivagens internas da Justiça do Trabalho que refletiram na atuação e na defesa de seus interesses dentro da ANC: 1 ) entre juízes dos TRTs e de primeiro grau, de um lado, em oposição ao TST; 2) entre juízes togados e classistas.

A oposição entre os juízes dos TRTs e de primeiro grau de um lado, e os Ministros do TST de outro, calcou-se na insatisfação dos juízes em relação ao conservadorismo e à atuação não democrática do órgão de Cúpula, o TST. A forma de escolha dos Ministros do TST, que claramente se dava por nomeação política vinculada ao Poder Executivo, desagradava à grande massa de juízes que não teria a oportunidade de se promover através de articulaçôes políticas. Em específico aos juízes dos TRTs, o tensionamento com o TST tratava-se de uma questão antiga, seguindo a path dependence institucional, iniciada em meados dos anos 60 quando os

18 "Eu mandei correspondência aos presidentes das associaçôes, se não tomasse cuidado, o que os parlamentares diziam, eles não faziam. Que realmente não eram confiáveis. [...] Imagina o que aconteceu, eu expedi de lá [Brasília] essa correspondência, na segunda-feira; na quinta-feira todo o Congresso Nacional recebeu uma cópia, vazou a informação, os classistas pegaram aquilo, um presidente de Associação que entregou para eles como um presente, e eles espalharam, pediram para que eu fosse processado, por que aquilo era um crime que lesa a Pátria, puseram lá um monte de coisa, que eu estava ofendendo a autoridade maior constituída do país, que era a ANC [...] Pedidos dos mais variados e levaram para quem isso, para Ulysses Guimarães. [...] O Ulysses Guimarães é uma pessoa de que eu respeito, da mais alta capacidade intelectual e sensibilidade política, que ele fez, imagina o que ele poderia ter feito. Todos os juízes brasileiros começaram a mandar telegrama, carta, telefonemas, que iam fazer um movimento, que aquilo não podia acontecer. E eu falei 'deixa fazer o que quiser, eu tenho as minhas garantias constitucionais e eu só posso ser julgado pelo Tribunal, que na época era o Tribunal de Recursos, eu tenho foro privilegiado'. Vão julgar pela ANC, mas qual o poder que a ANC tem? [...] O pessoal de São Paulo, mais próximo a Ulysses Guimarães, marcaram uma hora, fomos lá falar com ele. Não pedi favor político a ele, nós vamos expor nossa tese e ele nos recebeu. Todos falaram, e ele quieto, só olhando. E eu sentando como réu e eles me defendendo como meu advogado, meus colegas, e eu estava um pouco preocupado com o resultado daquilo, embora aparentemente não deixava transparecer nada. Quando terminou ele olhou para mim e disse: 'Dr. Chedid, você está famoso, eu já sei do seu nome, todo mundo sabe do seu nome aqui no Congresso, e você acha que eu vou deixar que o Senhor fique mais famoso e vou lhe dar a honra que nenhum brasileiro teve e nem vai ter, embora o senhor mereça, de ser processado pela ANC? Não Doutor, eu já rasguei aquela parafernália de bobagens que eles me mandaram'. Olha só a cabeça do homem. [...] Pois ele estava falando para mim, 'você acha que eu vou te dar uma oportunidade de toda mídia vim em volta de ti para tu defender a tua tese'. Era isso que ele não queria.” (sic) (CHEDID, 2011). 
TRTs concediam novos direitos em dissídios coletivos e o TST reformava os julgamentos.

Entretanto, foi no contexto da transição política e da redemocratização que se abriu a possibilidade de engajamento político dos magistrados que se articularam através da ANAMATRA, associação corporativista, passando a tomar posições públicas contra a atuação do TST. A ANAMATRA representava principalmente os juízes de primeiro grau, com poucas participações de juízes dos TRTs, embora não houvesse, nesta época, nenhuma disputa entre os dirigentes da Associação e os TRTs. Ou seja, a mudança institucional dentro da Justiça do Trabalho inicia-se neste momento devido às mudanças internas ocorridas dentro da própria magistratura, que aproveitando as novas ideias de democratização através dessas coligaçóes entre os agentes envolvidos na lutas - ANAMATRA, Amatras, juízes de primeiro grau e TRT - e abandonando consensos defendidos pelo TST, incrementalmente alteraram sutilmente a distribuição de poderes, o que seria o abandono do consenso contingente defendido por Levi (1991).

O descontentamento dos juízes trabalhistas ocorria com a falta de acessibilidade ao TST, que se encontrava fechado para aceitar outros órgáos e mesmo a associação dos juízes para tomadas de decisóes sobre interesses comuns a toda a magistratura trabalhista. Um desses assuntos referia-se à situação dos juízes classistas, pois enquanto a base dos magistrados togados começou a se manifestar pela a sua extinção, o TST, embora não tenha se posicionado, tinha seu presidente Marcelo Pimentel inclinado pela permanência dos classistas. Outro deles era sobre o aumento da competência da Justiça do Trabalho para incluir o julgamento dos trabalhadores avulsos, das empresas tomadoras de serviço e das relações de emprego dos servidores públicos, defendido pela ANAMATRA, mas não pelo presidente do TST, que apoiou somente a inclusão da competência para as relações de empregos dos servidores públicos.

O conflito entre os TRTs e TST sobre a reforma das decisões em dissídios coletivos relacionava-se com a amplitude do poder normativo. A ausência de lei disciplinando o poder normativo era a justificativa, utilizada pelo órgão revisor para impossibilitar a concessão das novas condições de trabalho, não prevista no ordenamento jurídico. Embora o tema gerasse o tensionamento na relação entre TRTs e TST, não provocou disputas na ANC entre os magistrados, pois havia um consenso, na época, sobre a necessidade da ampliação do poder normativo.

A outra clivagem da Justiça do Trabalho, entre juízes togados versus juízes classistas, começou a ficar mais visível dentro da Justiça do Trabalho neste mesmo 
período da redemocratização. $\mathrm{Na}$ época da Constituinte, o presidente do TST não se manifestou a respeito. Segundo o presidente da ANAMATRA no período, Marcelo Pimentel não tinha interesse em tomar um posicionamento público, em nome do TST, para não se indispor com uma grande parcela que defendia a permanência dos classistas, tanto no lado dos empregados como dos empregadores, pois tinha pretensóes de exercer cargos políticos após sua aposentadoria, que ocorreu em 1988. $\mathrm{Na}$ opinião do presidente da ANAMATRA, Marcelo Pimentel era mesmo a favor da permanência do vocalato. A evidência de que Marcelo Pimentel defendia o status quo a respeito do assunto foi encontrada em um artigo de jornal que escreveu na época em que o trabalho constituinte estava na Comissão de Sistematização, criticando a proposta de emenda que sugeria a eleiçáo direta nos sindicatos para a escolha dos juízes classistas em todos os graus de jurisdição. Essa situação confirma a desunião da classe profissional dos juízes togados, corroborando com a primeira clivagem apontada neste estudo.

$\mathrm{Na}$ ANC, a ANAMATRA centrou sua atuação na tese de extinção da representação classista, apontando que a mesma impediria a ampliação da competência da Justiça do Trabalho para abranger as relaçóes de trabalho dos trabalhadores eventuais, dos empreiteiros e dos servidores públicos federais, já que os vogais representavam apenas os trabalhadores com relação de emprego. Ademais, apontou a falta de conhecimento técnico jurídico dos juízes classistas, a aposentadoria na função, após pequeno período, e que o cargo se tratava de um ranço do sistema corporativo. Segundo o presidente da ANAMATRA na época, os classistas contaram com a atuação de uma empresa de lobby muito poderosa, com a utilização de muito dinheiro na busca de seus interesses ${ }^{19}$.

Embora a atuação da ANAMATRA tenha feito muita pressão para a extinção dos juízes classistas, no texto final aprovado, após a votaçáo em segundo turno no Plenário, os classistas permaneceram em todos os graus de jurisdição. A competência da Justiça do Trabalho não foi ampliada e o poder normativo foi garantido na sua forma mais ampla. Esse resultado evidencia que houve uma disputa de poder dentro da magistratura, dividida segundo as clivagens apontadas, mas no qual a força predominante junto aos constituintes foi do TST.

19 Os juízes classistas uniram-se em torno da Associação Nacional dos Juízes Classistas da Justiça do Trabalho (Anajucla). 


\section{A ANAMATRA na Reforma do Poder Judiciário: continuidade na defesa de extinção dos classistas e para a ampliação da competência da Justiça do Trabalho}

A Emenda Constitucional 24/1999, sobre a extinção da representação classista, e a Emenda Constitucional 45/2004, especificamente a ampliação da competência da Justiça do Trabalho para abranger todas as relaçóes de trabalho determinando a obrigatoriedade de um TRT por Estado e o aumento número de Ministros do TST, ambas inclusas no que ficou conhecido como a Reforma do Judiciário, também tiveram em suas tramitações a forte participação da ANAMATRA.

Os pontos que foram modificados na reforma do Judiciário na área do trabalho foram os mesmos que não eram consensuais na ANC de 1987/1988 e nem internamente no Judiciário trabalhista eram: a extinção dos juízes classistas, e o aumento da competência da Justiça do Trabalho. O poder normativo, que sofreu modificação na Reforma do Judiciário, tratou-se de uma exceção, pois na época da Constituinte havia a defesa consensual por sua ampliação, dentro do Judiciário Trabalhista, embora não houvesse entre os constituintes. A defesa da mitigação do poder normativo ocorreu por uma mudança de posicionamento do TST que passou a discordar sobre a sua utilidade, o que abriu espaço para uma disputa em torno do tema (FREITAS, 2012).

O tema da extinção da representação classista na Justiça do Trabalho foi muito polêmico na ANC de 1987/88, alvo de disputa acirrada entre a ANAMATRA, que pregava a sua extinção, e a Anajucla, que promoveu fortíssimo lobby pela sua permanência. Matéria que não foi consenso na $\mathrm{ANC}$, o tema voltou a ser posto em pauta nas discussões de reforma da Constituição, assim como aconteceu com a manutenção dos juízes classistas (FREITAS, 2012). Na Revisão Constitucional ${ }^{20}$, embora não tenham sido alterados os artigos constitucionais sobre a Justiça do Trabalho, o assunto foi objeto de mais de vinte emendas (BARRETO, 1995), cujas propostas previam desde a sua extinção, tese defendida por alguns congressistas e pela ANAMATRA, passando por algumas modificações na legislação, com a extinção da

\footnotetext{
${ }^{20}$ A Revisão Constitucional foi um meio formal de modificação da Constituição, através do Poder Constituinte Derivado, já previsto na Constituição de 1988, nos Atos das Disposições Constitucionais Transitórias, no artigo $3^{\circ}$, que dispôs que ocorreria após cinco anos, contados da promulgação da Constituiçáo, pelo voto da maioria absoluta dos membros do Congresso Nacional em sessão unicameral.
} 
aposentadoria dos vogais após cinco anos de exercício da função, até a manutenção do texto constitucional, apoiada pela maioria (57\%) dos congressistas e pela Anajucla.

Segundo Martins Filho (2000), a representação classista já era considerada como indesejável pela magistratura togada e pela sociedade, quando o presidente do Senado, Antônio Carlos Magalhães (PFL/BA), se posicionou a favor da sua extinção e se negou a constituir comissão especial para apreciar e sabatinar quatro indicaçóes de Ministros classistas para o TST, feitas pelo Presidente da República, no final de 1998.

A Emenda Constitucional 24/1999, que extinguiu a representação classista na Justiça do Trabalho, originou-se da PEC n. 63 de 1995, no Senado Federal, cujo autor foi o senador Gilberto Miranda (PSDB/SP), propondo a extinção dos juízes classistas em todos os graus de jurisdição. Em 20 de outubro de 1995, iniciou-se a discussão sobre a emenda, tramitando até 24 de maio de 1999 quando foi aprovada nessa Casa. Encaminhada para votação na Câmara dos Deputados, transformou-se na Emenda Constitucional n. 24 de 1999, isto em 09 de dezembro de 1999.

A ANAMATRA, através de sua presidente, a juíza Beatriz Lima Pereira, participou de audiência pública, apontando e parafraseando o Ministro Sepúlveda Pertence do STF que, se o representante classista fosse um bom juiz, seria um mau dirigente sindical e se fosse um atuante líder sindical, com certeza seria um mau juiz. Rebatendo os argumentos apontados pelos defensores do vocalato, apontou que a presença de leigos no Judiciário Trabalhista não evitaria o fenômeno da elitização, pois, em regra, os vogais eram atingidos por esse mal, inclusive promovendo as vexatórias "carteiradas" em situações da vida cotidiana. A democratização seria alcançada, principalmente, com a garantia do julgamento por órgão imparcial e independente, atributos com os quais os classistas não contavam. Acrescentou ainda que havia casos de envolvimento do vocalato com as denúncias de nepotismo que assombravam a Justiça do Trabalho, pois empregavam seus próprios parentes e emprestavam a sigla de seus sindicatos para indicação de parentes de juízes togados ao cargo de classistas. Questionou, além disso, o conhecimento técnico dos classistas para os julgamentos nos Tribunais e a representatividade dos classistas, citando o caso de um classista da regiáo de São Paulo, conhecidamente o polo industrial e financeiro do país, que vinha dos Sindicatos de Criadores de Proprietários de Cavalos de Corrida.

O posicionamento do TST e da ANAMATRA convergiram em relação à extinção dos juízes classistas, e o próprio Ministro Francisco Fausto afirmou que, na elaboração das cartilhas que enviou aos congressistas, defendeu a extinção do 
vocalato, utilizando para tanto os estudos da ANAMATRA ${ }^{21}$. A discussão sobre a extinção dos classistas, nesse momento, evidenciou que os assuntos polêmicos na ANC, aqueles sobre os quais não se firmou consenso entre os atores interessados que o disputavam (tanto constituintes, como atores externos), voltaram em pauta no período pós-Constituição, sendo novamente disputados pelos mesmos atores externos, como a ANAMATRA, porém, nesse momento os posicionamentos da ANAMATRA obtiveram êxitos. Além disso, mostrou atores individuais que participaram dos dois momentos, defendendo o mesmo posicionamento, como Antônio Carlos Facioli Chedid, que defendeu a extinção dos classistas, na época da Constituinte, através da ANAMATRA e, na época da Reforma do Judiciário, pelo Colégio de Presidentes e Corregedores de Tribunais Regionais do Trabalho (Coleprecor).

A PEC 96/1992, proposta pelo então deputado Hélio Bicudo (PT/SP), que originou a Emenda Constitucional 45/2004, recebeu esse número na Câmara dos Deputados. Nesta Casa, ocorreu a troca de relatoria quatro vezes, com dois arquivamentos e desarquivamentos, o apensamento de outras cinco emendas à Constituição, até que em 07 de junho de 2000 foi aprovado o projeto final. No Senado, com o n. 29/2000, passou por duas relatorias e depois de mais de doze anos, após sofrer muitas alterações desde o projeto inicial, originou a Emenda Constitucional 45/2004, publicada em 30 de dezembro de 2004.

$\mathrm{Na}$ área especifica da Justiça do Trabalho, propôs a extinção dos juízes classistas em todos os graus de jurisdição $0^{22}$, conforme as justificativas do autor: "A esse propósito, não tem mais sentido a organização ainda existente, com os juízes chamados classistas, despreparados para a função judicante e que mais dificultam do que agilizam a aplicação da Justiça para a classe trabalhadora” (BRASIL, 1992, p. 7852). Propôs também a mudança na composição do TST, prevendo que $4 / 5$ das vagas seriam destinadas aos juízes dos TRTs, nomeados pelo Presidente da República,

${ }^{21}$ O Ministro Francisco Fausto foi presidente do TST no período de 2002 a 2004 . Fausto, em entrevista concedida a Angela de Castro Gomes e Elina da Fonte Pessanha (GOMES e PESSANHA, 2010), em 15 de setembro de 2005, confirmou que o TST passou a agir mais incisivamente para aprovação de matérias de seu interesse junto ao Poder Legislativo, na presidência de Wagner Pimenta, ocasião em que este exercia o cargo de Corregedor-Geral. Esclareceu que foi o responsável pela elaboração das cartilhas que continham o posicionamento do TST sobre inúmeros aspectos da Justiça do Trabalho, com isso, apontando a importância de sua participação para a mudança de atuação política do TST.

22 O que se obteve com a PEC 63/95, ingressa no Senado, que originou a Emenda Constitucional 24 de 1999. 
e 1/5 das vagas aos membros do Ministério Público do Trabalho e aos advogados, indicados por lista tríplice; de forma semelhante, para a composição dos TRTs, destinava 4/5 das vagas aos juízes, nomeados pelo Presidente da República, com base em lista tríplice do TST, e 1/5 aos membros do Ministério Público do Trabalho e aos advogados, nomeados, também, por lista tríplice. A emenda deixava inalterada a competência da Justiça do Trabalho, consequentemente, também não alterava o poder normativo.

A participação da ANAMATRA na longa tramitação da PEC 96/92 foi intensa e se deu de maneiras diferentes. Nesse sentido enviou sua proposta para a Reforma do Poder Judiciário, juntamente com uma série de certidão emitidas por juízes de diferentes TRT, especificando as vantagens, os salários e as jornadas dos classistas, para demonstrar o alto valor pago por suas remuneraçóes, uma pequena jornada de no máximo 20 audiências por mês. A proposta dispôs sobre inúmeros assuntos: 1) a extinção da representação classista em todos os graus de jurisdição; 2) a volta da competência dos TRTs para o encaminhamento de projetos de lei ao Congresso Nacional, sob sua organizaçáo judiciária; 3) o aumento da competência da Justiça do Trabalho para abarcar além das relações de trabalho e dissídios coletivos, as causas dos servidores públicos ${ }^{23}$, mandados de segurança, habeas corpus, habeas data, crimes contra a organização do trabalho, conflitos intrassindical e intersindical, cobrança de multas decorrentes de infrações e dissídios coletivos. Com relação aos juízes classistas, apresentou ainda uma proposta alternativa, caso a primeira não fosse aceita: a diminuição de suas vagas em segunda e terceira instância e o seu reaproveitamento em órgãos de conciliação e arbitragem e em órgãos extrajudiciais de resolução de conflitos, observando que em todos os casos os classistas seriam eleitos diretamente pela categoria ${ }^{24}$.

A ANAMATRA também teve participação de audiência pública na Câmara dos Deputados, em 22 de agosto de 1996, quando defendeu a diminuição do poder normativo da Justiça do Trabalho expondo que não considerava razoável a legitimidade dos juízes trabalhistas para promover a criação de direitos e determinar os níveis de reajuste de salário.

\footnotetext{
${ }^{23}$ Ainda sobre esse assunto, a ANAMATRA enviou sugestão, propondo a ampliação da competência da Justiça do Trabalho para abarcar litígios, decorrentes das relaçóes de trabalho, inclusive dos servidores públicos, conforme o quadro explicativo das sugestões e emendas apresentadas por Bernardo Cabral, o último relator da PEC 96/92 na Câmara dos Deputados, em seu parecer.

${ }^{24}$ Os projetos e as certidóes forma obtidas no Arquivo sobre a Reforma do Poder Judiciário na Câmara Federal.
} 
A ANAMATRA não foi chamada a participar de audiência pública no Senado, o que não significou que nesta fase não tenha continuado a exercer pressão, principalmente para o aumento da competência da Justiça do Trabalho. Segundo o juiz presidente da ANAMATRA na época, Grijalbo Fernandes Coutinho, em entrevista concedida, a ANAMATRA foi muito atuante em todo o período, além disso, apontou que houve um alinhamento entre o posicionamento da ANAMATRA e do TST, nos últimos anos da tramitação da Reforma do Judiciário (GOMES e PESSANHA, 2010).

\section{Conclusões}

O institucionalismo histórico, defendendo que a causalidade social dependente da trajetória percorrida pela instituição, path dependence, busca explicar como as próprias instituições, através de políticas adotadas no passado, acabam condicionando as políticas ulteriores. A atuação e as conquistas da ANAMATRA, no que toca os artigos constitucionais referentes à Justiça do Trabalho, podem ser atribuídas aos espaços que a ANAMATRA conquistou, às instituiçôes as quais se aliou e ao papel das ideias nas mudanças institucionais.

$\mathrm{Na}$ época da Constituinte de 1987-88, a ANAMATRA não tinha acesso ao órgão de cúpula do Judiciário Trabalhista, o TST, pois se chocavam os posicionamentos defendidos: o conservadorismo imperava no TST e a ANAMATRA defendia ideias mais progressistas. Essa clivagem ficou evidente no Judiciário Trabalhista: de um lado, os juízes de primeiro grau, com apoio dos TRTs, associados à ANAMATRA, e de outro, o TST. A ANAMATRA defendeu a extinção dos juízes togados, a alteração na escolha e nomeação dos Ministros do TST, bem como o aumento da competência da Justiça do Trabalho para todas as relações de trabalho. Nenhuma de suas propostas obtiveram êxito.

$\mathrm{Na}$ Reforma do Poder Judiciário, outro foi o panorama. Nesse momento, as instituiçóes foram influenciadas pela difusão de ideias. As ideias da democracia influenciaram o TST, que passou agir em conjunto com a ANAMATRA, após passar por inúmeras alteraçóes internas (FREITAS, 2012), fazendo prosperar os pontos defendidos por ambos: extinção dos juízes classistas e aumento da competência da Justiça do Trabalho. A alteração na relação da ANAMATRA com o TST possibilitou ganhos políticos em termos de conquista de artigos constitucionais sobre a organização do Poder Judiciário Trabalhista.

A experiência institucional da ANAMATRA em participar da ANC de 19871988 foi importante para ancorar sua atuação política na tramitação das PECs da 
Reforma do Poder Judiciário, principalmente com a participação de audiências públicas, enviando propostas e manifestaçóes de juízes de primeiro grau.

Lígia Barros de Freitas é Doutora em Ciência Política pela Universidade Federal de São Carlos - UFSCar. Pesquisadora do CEIPOC - Unicamp. E-mail: ligiadefreitas@ig.com.br.

\section{Referências}

ARTUR, Karen. O novo poder normatizador do TST: dissídios individuais e atores coletivos. São Paulo: LTr, 2012.

BARRETO, Túlio Velho. O Debate Recente Acerca da Representação Classista na Justiça do Trabalho. Cadernos de Estudos Sociais (FUNDAJ), Recife, v. 11, n. 2, p. 177-197, 1995.

BRASIL. Câmara dos Deputados. Proposta de Emenda à Constituição n. 96 de 1992. Diário do Congresso Nacional (Seção I), 1992. Disponível em: $<$ http://imagem.camara.gov.br/dc_20b.asp?largura=\&altura $=\&$ selCodColecaoCsv=D\&Datain $=01$ \%2F05\%2F1992\&txPagina $=7840 \&$ txSuplemento=0\&enviar=Pesquisar $>$. Acesso em: 06 out 2011.

Assembleia Nacional Constituinte, Atas de Comissóes, Atas da Subcomissão do Poder Judiciário e do Ministério Público, 1987. Disponível em: <http:// www.congresso.gov.br/anc88/>. Acesso em: 16 set. 2008.

CARVALHO, Ernani Rodrigues de. Em busca da judicialização da política no Brasil: apontamentos para uma nova abordagem. Revista de Sociologia Política, Curitiba, n. 23, p. 115-126, nov. 2004.

CHEDID, Antônio Carlos Facioli. Presidente da ANAMATRA entre 1987 e 1989. 25 ago. 2011. Entrevista concedida a Lígia Barros de Freitas.

ENGELMANN, Fabiano. Sociologia do campo juridico: juristas e usos do direito. Porto Alegre: Sérgio Antonio Fabris Editor, 2006.

FREITAS, Lígia Barros de. A consolidação institucional do Tribunal Superior do Trabalho (TST) na longa Constituinte (1987-2004). 2012. 373p. Tese (Doutorado em Ciência Política) - Programa de Pós-Graduação em Ciência Política, Universidade Federal de São Carlos, São Carlos, 2012.

GOMES, Ângela de Castro; PESSANHA, Elina Gonçalves. Memória da Justiça do Trabalho: trajetória de juízes. Porto Alegre: Alegre Poa, 2010.

HALL, Peter A.; TAYLOR, Rosemary C. R. As três versôes do neo-institucionalismo. Lua Nova, n. 58, p. 192-223, 2003.

IMMERGUT, Ellen Margaretha. As regras do jogo: a lógica da política de saúde na França, na Suíça e na Suécia. Revista Brasileira de Ciências Sociais, São Paulo, v. 11, n. 30, p. 139-165, 1996.

LEVI, Margaret. Uma lógica da Mudança Institucional. Dados - Revista de Ciências Sociais, Rio de Janeiro, v. 34, n. 1, p. 79-99, 1991. 
MAHONEY, James; THELEN, Kathleen. A Theory of Gradual Institucional Change. In: MAHONEY, James; THELEN, Kathleen (Eds). Explaining Institutional Change: Ambiguity, Agency, and Power. Cambridge: Cambridge University Press, 2010. p. 1-37.

MARTINS FILHO, Ives Gandra da Silva. A Justiça do Trabalho do ano de 2000. As Leis 9756/1988 e 9958/2000, a Emenda Constitucional de 24/1999 e a Reforma do Judiciário. Revista Jurídica Virtual, Brasília, v. 1, n. 8, jan. 2000. Disponível em: < http://www.planalto.gov.br/ccivil_03/revista/Rev_08/just_trabalho.htm>. Acesso em: 18 out 2011.

MOREL, Regina Lúcia Moraes; PESSANHA, Elina Gonçalves da Fonte. Magistrados do Trabalho no Brasil: entre a tradição e a mudança. Estudos Históricos, Rio de Janeiro, n. 37, p. 29-53, jan.-jun. 2006.

PODER NORMATIVO. In: Vocabulário Jurídico. Tribunal Superior do Trabalho. 2012. Disponível em: <http:/www.tst.jus.br/vocabulario-juridico >. Acesso em: 26 nov. 2014.

TAYLOR, Matthew M. O Judiciário e as Políticas Públicas no Brasil. Dados - Revista de Ciências Sociais, Rio de Janeiro, v. 50, n. 2, p. 229-257, 2007.

THELEN, Katheleen; STEINMO, Sven. Historical institucionalism in comparative politics. In: STEINMO, Sven; THELEN, Katheleen; LONGSTRETH, Frank. Structuring politics: Historical instittucionalism in comparative analysis. New York: Cambridge University Press, 1992. p. 1-32.

THÉRET, Bruno. As Instituições entre as estruturas e as ações. Lua Nova, São Paulo, n. 58, p. 225$254,2003$.

Texto recebido em 29 de agosto de 2014. Aprovado em 15 de outubro de 2014. 
